\title{
A REVIEW ON ROLE OF ANTIOXIDANTS IN DIABETES
}

\section{DEEPA RAJENDIRAN ${ }^{1,2}$, SUBBULAKSHMI PACKIRISAMY ${ }^{3}$, KRISHNAMOORTHY GUNASEKARAN ${ }^{4 *}$}

${ }^{1}$ Department of Biochemistry, Research and Development Centre, Bharathiar University, Coimbatore, Tamil Nadu, India. ${ }^{2}$ Department of Biochemistry, Madha Dental College and Hospital, Kundrathur, Chennai, Tamil Nadu, India. ${ }^{3}$ Department of Pharmacology, Meenakshi Ammal Dental College and Hospital Maduravoyal, Chennai, Tamil Nadu, India. ${ }^{4}$ Department of Biochemistry, Rajas Dental College and Hospital, Kavalkinaru Junction, Tirunelveli, Tamil Nadu, India. Email: krishgunabio@gmail.com

Received: 23 October 2017, Revised and Accepted: 15 November 2017

\section{ABSTRACT}

Diabetes mellitus is a chronic metabolic disease. Oxidative stress plays a major part in the pathogenesis of diabetes. Supplementation with antioxidants and the medicinal plants which possess antioxidants activity have been reported their hypoglycemic activity. The antioxidants are used to treat and reduce the complication of diabetes mellitus. The diet supplementations of antioxidants vitamins are beneficial in the treatment of diabetes. This review article was summarizing the role of antioxidants in diabetes mellitus.

Keywords: Antioxidants, Diabetes mellitus, Oxidative stress, Medicinal plants.

(C) 2018 The Authors. Published by Innovare Academic Sciences Pvt Ltd. This is an open access article under the CC BY license (http://creativecommons. org/licenses/by/4. 0/) DOI: http://dx.doi.org/10.22159/ajpcr.2018.v11i2.23241

\section{INTRODUCTION}

Diabetes mellitus is an insistent metabolic disorder characterized by an aberrantly upraised level of blood glucose due to the deficit in insulin secretion by the $\beta$-cells of the pancreas and/or resistance toward the exploit of hormone insulin associated with disturbances in the carbohydrates, lipids, and proteins metabolism which leads to long-term complications. International Diabetes Federation conferring 371 million people affected by diabetes and the number likely to elevate 552 million by 2030 . Based on the previous experimental and clinical studies recommend that oxidative stress plays a main role in the pathogenesis of diabetes. This article reviews the role of antioxidants in diabetes [1].

\section{FREE RADICALS}

Free radicals are a molecule with one or more single pair of the electron that can quickly react with the constituents such as proteins, nucleic acid, and lipids. The reactive molecule comprises the reactive oxygen species (ROS) and reactive nitrogen species was derived from oxygen and nitrogen, respectively. These reactive particles are generated in cellular membrane, mitochondria, nucleus, lysosome, peroxisome, endoplasmic reticulum, and cytoplasm. The enhanced generation of the reactive species associated with hyperglycemia [2].

\section{OXIDATIVE STRESS AND DIABETES}

Oxidative stress plays a key role in the development of wide range of diseases including cancer, cardiovascular disease, diabetes, aging, liver, and lung diseases. Oxidative stress due to an imbalance between radical engendering and radical scavenging systems. Previous experimental studies have been reported overproduction of free radicals and defect of antioxidants protection involved pathogenesis of diabetes [3]. The mechanism behind the prooxidant-antioxidant imbalance in diabetes mellitus is auto-oxidation of glucose, increased the formation of advanced glycation end products (AGEs), polyol pathway, hexosamine pathway, and mitochondrial respiratory chain. The enzymatic source of free radical generation includes nitric oxide synthase, NADPH oxidase, and xanthine oxidase [4].

\section{CHEMICAL CAUSES OF DIABETES}

In most of the animal research, the chemicals or drug is used for the induction of diabetes. The well-known chemical compound used in diabetic research is alloxan; it is a toxic compound which destroys the beta-cells of the pancreas. In previous research, alloxan used to induce type 1 diabetes in animals such as rat, mice, and rabbits. Nowadays, instead of alloxan, streptozotocin used for induction of Types 1 and 2 diabetes due to their toxicity and instability [5].

Streptozotocin is a glucosamine nitrosourea compound has a chemical name of 2-deoxy-2(methyl nitrosamino)carbonyl)amino)-D-glucose derived from a fermentation broth of Streptomyces achromogenes. It is toxic glucose analog generally used to induce experimental diabetes. Rakieten et al. [6] were the first to demonstrate that STZ-induced diabetes in an animal model. Based on the previous experimental model, it is frequently used single intravenous dose between 40 and $60 \mathrm{mg} / \mathrm{kg}$ of body weight [7].

The streptozotocin enters into the beta-cells of pancreas through glucose transporter 2 (GLUT 2). The mechanism behind the streptozotocin action in the beta-cell is DNA alkylation due to the presence of methyl nitrosourea moiety. Transfer of methyl group from streptozotocin to DNA cause damage, resulting in the formation of DNA fragmentation [8]. However, the synergistic action of nitric oxide and ROS it may contribute beta-cell destruction. The damage to DNA activates poly ribosylation; it leads to depletion of NAD and ATP eventually may lead to beta-cell death [9].

\section{ANTIOXIDANTS}

Antioxidants are substances able to slow or inhibit the oxidation of other molecules. Recently, the medicinal field focused the antioxidants therapy in the management of numerous diseases, especially diabetes. Preceding experimental studies and clinical trials have suggested the efficacy of antioxidants in preventing diabetes complication. The therapeutic strategy uses the antioxidants as a substrate, combined drug, synthetic antioxidants, and drug with antioxidants activity. In general, the medicinal plants with antioxidants activity are considered for the treatment of diabetes mellitus [10].

\section{ROLE OF ANTIOXIDANTS IN DIABETES}

The antioxidants therapy defends the beta-cell against oxidative stressinduced apoptosis and preserves the function of the beta-cell. Data from earlier studies show the antioxidants diminish diabetic-related complication and recover insulin sensitivity. Epidemiological studies 
revealed a strong association between the dietary antioxidants intake and protection against diabetes.

\section{Vitamin E}

It is naturally occurring lipophilic antioxidant exists as tocopherol and tocotrienol. It defends the cell against oxidative damage. It is believed Vitamin E playing a key role in controlling hyperglycemia, and the combined antioxidants therapy also considered for control and prevention of diabetic complication. The studies in an animal model have shown supplementation of Vitamin E decreases the hepatic lipid peroxide level in streptozotocin-induced diabetes [11]. However, the increased level of lipid peroxide due to change of antioxidant status in the diabetic rat.

Dietary vitamin and administration of Vitamin E positively associated with glucose concentration. The level of glucose significantly decreased and the OGGT improved in diabetic condition by supplementation of Vitamin E [12]. During diabetic condition, the antioxidant enzymes SOD, CAT, and GPX decreased. However, the oral administration of Vitamin E (440 mg/kg of body weight, once a week for 30 days) significantly increased SOD and GSH-Px activity and decreased the hydroperoxide level due to an improvement of glycemia [13].

During diabetic condition, the excess glucose attached to hemoglobin to produce glycosylated hemoglobin. It is an important marker for diabetes which is prevented Vitamin E treated rat in diabetic condition [14].

Vitamin E has been shown to controls hyperglycemia and lowering the HbA1c by inhibiting the sequence of oxidative stress in diabetic rats [15]. The mechanism by which antioxidants reduced the glucose levels not yet clear, but the plasma glucose level decreased by increasing the glucose metabolism in peripheral tissues [16]. Supplementation of Vitamin E (1800IU/day) showed that the serum level of Vitamin E increases in Type 1 diabetes and control rats, whereas the retinal blood flow significantly increased and elevated baseline creatinine clearance normalized, but the $\mathrm{HbA1C}$ level not affected in the same experiment. It is achieved by unchanged glycemic control and normalization of DAG/PKC pathway through activation of DAG kinase in diabetic patients [17].

In synergy with $\beta$-carotene and Vitamin $\mathrm{C}$, it is reduced the risk of diabetes and cancer. The antioxidant property of Vitamin E associated with the prevention of hyperglycemia and minimizes the macrovascular and microvascular complications in individuals with diabetes [18].

\section{Vitamin C}

It is powerful antioxidants scavenging free radicals in aqueous compartment. It is essential to convert Vitamin E free radicals to Vitamin E, as a cofactor required for hydroxylation reaction in human. The most important function of Vitamin C is key chain-breaking antioxidants in the aqueous phase. It provides stability to the cell membrane.

The research conducted by Yazd Diabetes Research Center, Iran, has been reported that totally 84 diabetic patients received $500 \mathrm{mg}$ or $1000 \mathrm{mg}$ of ascorbic acid daily for 6 weeks. The daily consumption of $1000 \mathrm{mg}$ of Vitamin C may be beneficial in reducing blood glucose level and lipids, whereas $500 \mathrm{mg}$ not significantly made any change during the parameter studied [19].

Eriksson and Kohvakka studied the effect of Vitamin C supplementation ( $2 \mathrm{~g} /$ day for 90 days) in 56 diabetic patients; the result has shown the high-dose supplementation reduced the level of fasting blood glucose, HbA1c and improve glycemic control [20]. Frequent intake of Vitamin C dietary source was found to decrease the risk of Type 2 diabetes in a population-based study [21]

Administration of Vitamin C and E (100 mg/kg of body weight of rat) significantly reduced the blood glucose level [22]. However, lowered level of ascorbic acid and SOD observed in the diabetic subject when compared to the non-diabetic person [23]. The increased level of
Vitamin $\mathrm{C}$ in diabetes may due to increased utilization in trapping the oxyradicals. Some of the studies have been reported that diabetes may result in decreased plasma Vitamin $\mathrm{C}$ and $\mathrm{E}$ due to increased oxidative stress [24].

The mechanism behind the treatment of diabetes is not clear. However, it diminishes the microalbuminuria, erythrocyte sorbitol levels and plays a chief role in ameliorating insulin resistance of diabetic patients due to its antioxidant function $[25,26]$.

\section{Alpha-lipoic acid}

A potent antioxidant, it is also known as 1, 2-dithiolane-3-pentanoic acid or thioctic acid.

Alpha-lipoic acid fights cellular injuries triggered by free radicals, those unstable, highly reactive molecules that are derivatives of both normal and frazzled cell activity. It has a capability to restore endogenous antioxidants such as glutathione, Vitamin E, and Vitamin C. It is effective in many pathological conditions such as cardiovascular disease, diabetes mellitus, and liver disease $[27,28]$

Alpha-lipoic acid has been reported to progress glucose metabolism in Type 2 diabetes mellitus patient by directly activate lipid, tyrosine, and serine/threonine kinases in target cells, due to these mechanisms which stimulate glucose uptake and glycogenesis. In vitro studies have reported that the alpha-lipoic acid increases the translocation of GLUT1 and GLUT4 to the plasmatic membrane of adipocytes and skeletal muscle. It is related to an improved activity of proteins of insulin signaling pathway [29].

Budin et al. [30] had reported that the intake of ALA reduced the glucose level and total cholesterol in STZ-induced diabetes in rats. It also regenerates the other antioxidants such as Vitamin C, Vitamin E, and SOD in diabetic condition. The same results have been previously reported in experimental animals [31].

Jacob et al. have been reported that the administration of $500 \mathrm{mg}$ of ALA in Type 2 diabetes patients for 10 days shown a significant increase of insulin-stimulated glucose disposal (30\%) and no changes observed in fasting plasma glucose level or insulin. In the clinical study, 20 patients received $500 \mathrm{mg}$, it able to improve insulin resistance in NIDDM [32]. Same results were obtained by chronic administration $(100 \mathrm{mg} / \mathrm{kg})$ of antioxidant in type 2 diabetes mellitus [33].

In another study, the oral supplementation ALA (600 mg twice daily for 4 weeks) treatment which increases the plasma insulin sensitivity [34]. According to Packer et al., ALA is capable to scavenge ROS produced during the lipid peroxidation and guards the cell structure against damage. The continued supplementations of the LA in diabetic rats were associated with diminution of both hyperglycemia and diabetic nephropathy [35].

\section{Selenium}

It is important trace element, naturally present in many foods. It exists in organic and inorganic forms. Selenomethionine and selenocysteine belong to organic form; selenate and selenite are inorganic forms. Mostly the inorganic selenite presents in the soil. Selenium plays a major role in thyroid hormone metabolism and immune functions. Based on previous experimental and clinical studies, selenium focused on the prevention of many diseases due to their antioxidant activity [36].

Previously, selenium was found as a toxic component due to Se poisoning in animals and humans, thereafter, it was recognized as essential element since selenium deficiency considered a major problem in animal and human [37]. The supplementation of selenium with low doses has a beneficial effect on glucose metabolism, which mimics insulin-like actions in the animal experimental model. While the mechanism behind the mimicking insulin is not clear, however, the previous report showed that Se activates the key protein responsible for insulin signal cascade [38]. 
The inorganic selenium compound sodium selenate and sodium selenite involved in insulin signaling cascade by activation of kinases. In animal experimental studies shown selenate stimulate glucose uptake and involved phosphorylation of insulin receptor and insulin receptor substrate $1[39,40]$ and the oral administration or intraperitoneal injection of daily doses of selenate for 3-8 weeks in streptozotocininduced diabetic rat, the result shown that the raised glucose level to be reduced $[41,42]$

In another study stated the above-mentioned insulin-like activity of selenium due to increased glucose tolerance and alteration in the activity of gluconeogenic and glycolytic maker enzyme. In the same way, selenomethionine also studied their antioxidant activity in a diabetic animal, supplementation of selenomethionine, Vitamin E plus selenomethionine in type I diabetic rat for 24 weeks effectively decreased the glucose and glycosylated hemoglobin level [43].

Numerous studies have reported that Vitamin E, C, and alpha-lipoic acid and selenium frequently used antioxidants in the management of diabetes. Nowadays, the antioxidants-based formulation developed for the treatment of various diseases. Table 1 summarizes antioxidants efficacy of vitamins in diabetes.

\section{MEDICINAL PLANTS IN DIABETES}

Medicinal plants are tremendous in the treatment of numerous diseases due to their antioxidant activity. All parts of medicinal plants are effective in the treatment of disease and help to discover new kind of drug. The plants contribute a potential source of hypoglycemic drugs due to their phytoconstituents [44].

The active constituents responsible for hypoglycemic activity may include polysaccharides, sterol, triterpenoid, alkaloids, flavonoids, fat, coumarins, phenolics, and peptides. It stimulates the beta-cell to restore the function of pancreatic tissue [45]. The insulin secretion in beta-cell increased and the uptake of glucose increased by adipose tissue and muscle in plant treated rat, at same the time the absorption of glucose decreased and hepatic glucose production decreased by inhibiting the enzymes [46]. Some of the antidiabetic plants possess antioxidants activity include Nerium oleander Linn. [47], Annona squamosa [48], Cynodon dactylon [49], Padina boergesenii [50], and Tectona grandis Linn. [51]. Table 2 summarizes antidiabetic plants which possess antioxidants activity. Medicinal plants have a long history in the treatment of diseases majorly in diabetes; therefore, it focused mainly due to its curative property with fewer side effects.

Table 1: Antioxidant efficacy of vitamins and supplements in diabetes

\begin{tabular}{|c|c|c|c|c|}
\hline Antioxidants & Dosage & Diabetogen & Efficacy & Reference \\
\hline Vitamin E & $\begin{array}{l}500 \mathrm{mg} / \mathrm{kg} \text { on the day } 1,4 \text {, } \\
7,11,14.21,24,27\end{array}$ & $\begin{array}{l}\text { Streptozotocin (single dose } \\
60 \mathrm{mg} / \mathrm{kg} \text { body weight) }\end{array}$ & $\begin{array}{l}\text { Lowered lipid peroxide level } \\
\text { in the liver of the diabetic rat }\end{array}$ & Seven et al. (2004) \\
\hline Vitamin C & $500 \mathrm{mg}$ twice a day & $\begin{array}{l}\text { Type } 1 \text { and } 2 \text { diabetic } \\
\text { patients }\end{array}$ & $\begin{array}{l}\text { Supplementation of Vitamin C } \\
\text { with metformin reduces FBS, } \\
\text { PMBG and improves HbA1c. }\end{array}$ & Ganesh et al. (2011) \\
\hline Vitamin E + Vitamin C & $\begin{array}{l}\text { Vitamin C } 60 \text { mg daily and } \\
\text { Vitamin E } 200 \mathrm{mg} \text { twice a } \\
\text { week for } 5 \text { weeks }\end{array}$ & $\begin{array}{l}\text { STZ (single dose } 75 \mathrm{mg} / \mathrm{Kg} \\
\text { body weight) }\end{array}$ & $\begin{array}{l}\text { Reduced hepatic lipid peroxide, } \\
\text { normalized Vitamin C, and } \\
\text { raised Vitamin E above the } \\
\text { normal level. }\end{array}$ & Madhu et al. (2000) \\
\hline Alpha-lipoic acid & 300 mg daily & Type 2 diabetic patients & Decreased FBS and IR & Hasti et al. (2011) \\
\hline $\begin{array}{l}\text { Selenium } \\
\text { (sodium selenite) }\end{array}$ & $0.5 \mu \mathrm{g} /$ day & STZ (55 mg/kg body weight) & $\begin{array}{l}\text { Selenium reduced oxidative } \\
\text { stress associated diabetes }\end{array}$ & Mukherjee et al. (1998) \\
\hline
\end{tabular}

Table 2: Shows the antidiabetic plants which possess antioxidants activity

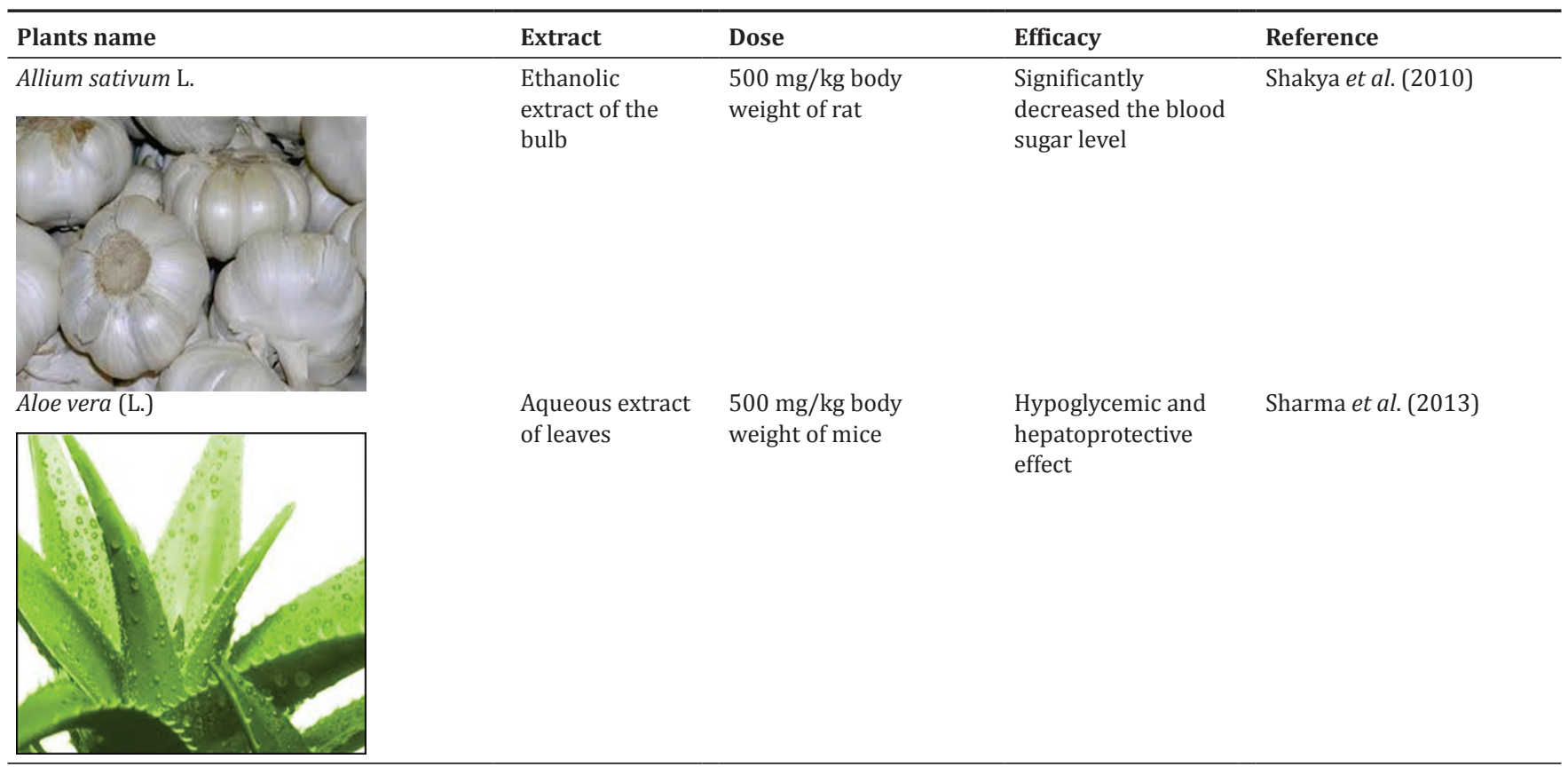


Table 2: (Continued)

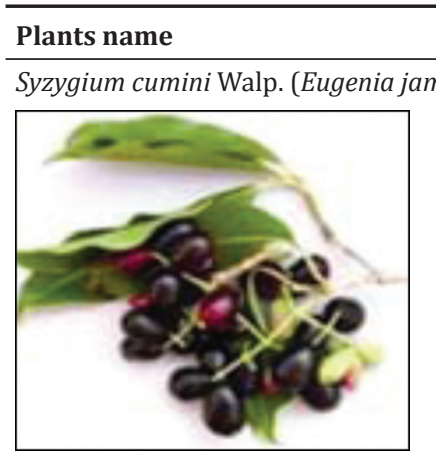

Mimosa pudica

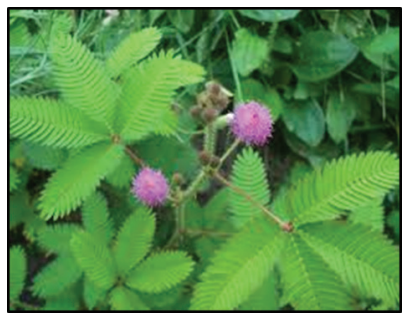

Momordica charantia

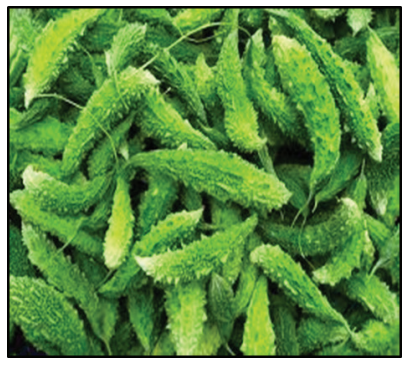

Psidium guajava

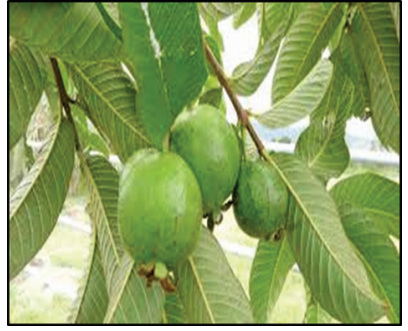

Mangifera indica

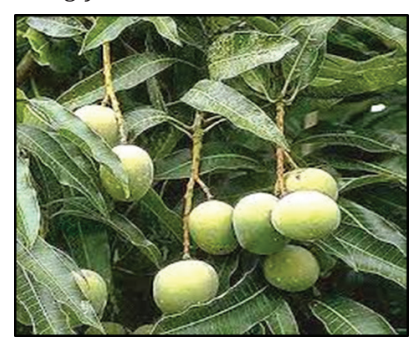

Andrographis paniculata

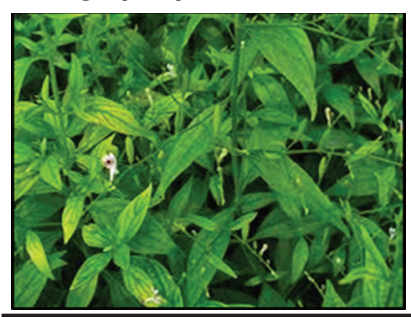

$\begin{array}{llll}\text { Extract } & \text { Dose } & \text { Efficacy } & \text { Reference } \\ \text { Seed powder } & \begin{array}{l}500 \text { and } 1000 \mathrm{mg} / \mathrm{kg} \\ \text { body weight of rat }\end{array} & \begin{array}{l}\text { Hypoglycemic } \\ \text { activity }\end{array} & \text { Sridhar } \text { et al. (2005) }\end{array}$

Thottal vadi $\quad 100$ and $200 \mathrm{mg} / \mathrm{kg}$

choornam

(Leaves and

roots)

Alcoholic

extract of bitter

melon

Ethanolic

extract of leaf

$250 \mathrm{mg} / \mathrm{kg}$ of body

weight of rat

$300 \mathrm{mg} / \mathrm{kg}$ of body weight of rat

extract of seed

kernels
0.5-1.5 g/kg body weight of rabbits.
Hypoglycemic activity

Hypoglycemic activity
Vishwanathan et al. (2013) activity

Hypoglycemic activity

Vangoori et al. (2013)

Mukhtar et al. (2004)

Gupta and Gupta (2011)
Ethanolic extract. (Aerial part)
$0.1,0.2$, and $0.4 \mathrm{~g} /$ body
weight of rat.

Hypoglycemic and hypotriglyceridemic effect
Zhang et al. (2000) 


\section{CONCLUSION}

Among the antioxidants, the diet-derived antioxidants are important in the prevention and management of various diseases. Over the past decades, antioxidant-based experimental research emerged in the production of a new drug. However, many drugs are in clinical trials which possess antioxidants activity.

Based on the review, supplementation of antioxidants such as Vitamin E, C, alpha-lipoic acid, and selenium shows their hypoglycemic and hepatoprotective effect, but some of the studies have been reported that vitamin supplementation does not affect glucose level. In diabetic condition, the low level of vitamin reported in the previous study. The mechanism behind the antioxidant is undefined, most of the study reported it prevent and minimize the complication of diabetes.

\section{REFERENCES}

1. Khavandi K, Amer H, Ibrahim B, Brownrigg J. Strategies for preventing Type 2 diabetes: An update for clinicians. Ther Adv Chronic Dis 2013;4:242-61.

2. Halliwell B, Guttreridge JM, editors. Free Radical in Biology and Medicine. Oxford and New York: Clarendon Press; 1999.

3. Opara EC. Oxidative stress, micronutrients, diabetes mellitus and its complications. J R Soc Promot Health 2002;122:28-34.

4. Singh PP, Mahadi F, Roy A, Sharma P. Reactive nitrogen species and antioxidants in etiopathogenesis of diabetes mellitus Type 2. Indian $\mathbf{J}$ CLIN Biochem 2009;24:324-42.

5. Lenzen S. The mechanisms of alloxan-and streptozotocin-induced diabetes. Diabetologia 2008;51:216-26.

6. Rakieten N, Rakieten ML, Nadkarni MV. Studies on the diabetogenic action of streptozotocin (NSC-37917). Cancer Chemother Rep $1963 ; 29: 91-8$.

7. Ganda OP, Rossini AA, Like AA. Studies on streptozotocin diabetes. Diabetes 1976;2:595-603.

8. Pieper AA, Verma A, Zhang J, Snyder SH. Poly (ADP-ribose) polymerase, nitric oxide and cell death. Trends Pharmacol Sci 1999;20:171-81.

9. Yamamoto H, Uchigata Y, Okamoto H. Streptozotocin and alloxan induce DNA strand breaks and poly(ADP-ribose) synthetase in pancreatic islets. Nature 1981;294:284-6.

10. Kelly FJ. Use of antioxidants in the prevention and treatment of disease. J Int Fed Clin Chem 1998;10:21-3.

11. Seven A, Guzel S, Seymen O, Civelek S, Bolayirli M, Uncu M, et al. Effects of vitamin $\mathrm{E}$ supplementation on oxidative stress in streptozotocin induced diabetic rats: Investigation of liver and plasma. Yonsei Med J 2004;45:703-10.

12. Al Shamsi MS, Amin A, Adeghate E. Beneficial effect of vitamin E on the metabolic parameters of diabetic rats. Mol Cell Biochem 2004;261:35-42.

13. Baragob AE, Al Malki WH, Alla WH, Ibrahim A, Muhammed SK, Abdella S. Investigate evaluation of oxidative stress and lipid profile in STZ-Induced rats treated with antioxidant vitamin. Pharmacol Pharm 2014:5:272-9.

14. Je HD, Shin CY, Park HS, Huh IH, Sohn UD. The comparison of vitamin $\mathrm{C}$ and vitamin $\mathrm{E}$ on the protein oxidation of diabetic rats. J Auton Pharmacol 2001;21:231-6.

15. Ihara Y, Yamada Y, Toyokuni S, Miyawaki K, Ban N, Adachi T, et al. Antioxidant alpha-tocopherol ameliorates glycemic control of GK rats, a model of Type 2 diabetes. FEBS Lett 2000;473:24-6.

16. Roldi LP, Pereira RV, Tronchini EA, Rizo GV, Scoaris CR, Zanoni JN, et al. Vitamin E (alpha-tocopherol) supplementation in diabetic rats: Effects on the proximal colon. BMC Gastroenterol 2009;9:88.

17. Bursell SE, Clermont AC, Aiello LP, Aiello LM, Schlossman DK, Feener EP, et al. High-dose vitamin E supplementation normalizes retinal blood flow and creatinine clearance in patients with Type 1 diabetes. Diabetes Care 1999;22:1245-51.

18. Milman U, Blum S, Shapira C, Aronson D, Miller-Lotan R, Anbinder Y, et al. Vitamin E supplementation reduces cardiovascular events in a subgroup of middle-aged individuals with both Type 2 diabetes mellitus and the haptoglobin 2-2 genotype: A prospective double-blinded clinical trial. Arterioscler Thromb Vasc Biol 2008;28:341-7.

19. Afkhami-Ardekani M, Shojaoddiny-Ardekani A. Effect of vitamin C on blood glucose, serum lipids and serum insulin in Type 2 diabetes patients. Indian J Med Res 2007;126:471-4.

20. Eriksson J, Kohvakka A. Magnesium and ascorbic acid supplementation in diabetes mellitus. Ann Nutr Metab 1995;39:217-23.

21. Williams DE, Wareham NJ, Cox BD, Bryne CD, Hales CN, Day NE. Frequent salad vegetable consumption is associated with a reduction in the risk of diabetes mellitus. J Clin Epidemiol 1999;52:329-35.

22. Tanko Y, Eze ED, Chukwuemeka UE, Jimoh A, Mohammed A, Abdulrazak A, Modulatory roles of vitamin C and E on blood glucose and serum electrolytes levels in fructose-induced insulin resistance (Type 2) diabetes mellitus in wistar rats. Pharm Lett 2013;5:259-63.

23. Will JC, Bowman BA. Serum vitamin-C concentrations and diabetes: Finding from the third national health and nutrition examination survey, 1988-1994. Am J Clin Nutr 1999;70:49-52.

24. Hisalkar PJ, Patne AB, Fawade MM. Assessment of plasma antioxidant levels in Type 2 diabetes patients. Int J Biol Med Res 2012;3:1796-800.

25. Paolisso GD, Amore A, Balbi V, Volpe C, Galzerano D, Giugliano D, et al. Plasma vitamin $\mathrm{C}$ affects glucose homeostasis in healthy subjects and non-insulin dependent diabetics. Am J Physiol 1994;266:261-68.

26. Cunningham JJ, Mearkle PL, Brown RG. Vitamin C: An aldose reductase inhibitor that normalizes erythrocyte sorbitol in insulindependent diabetes mellitus. J Am Coll Nutr 1994;13:344-50.

27. Wollin SD, Jones PJ. Alpha lipoic acid and cardiovascular disease. J Nutr 2003;133:3327-30.

28. Bustamante J, Lodge JK, Marcocci L, Tritschler HJ, Packer L, Rihn BH. Alpha-lipoic acidin liver metabolism and disease. Free Radic Biol Med 1998;24:1023-39.

29. Lester Packe and Enrique Cadenas. Lipoic acid: Energy metabolism and redox regulation of transcription and cell signaling. J Clin Biochem Nutr 2011;48:26-32.

30. Budin SB, Kee KP, Eng MY, Osman K, Bakar MA, Mohamed J. Alpha lipoic Acid prevents pancreatic islet cells damageand dyslipidemia in streptozotocin-induced diabetic rats. Malays J Med Sci 2007; $14: 47-53$.

31. Arambasic J, Mihailovic M, Uskokovic A, Dinic S, Grdovic N, Markovic J, et al. Alpha-lipoic acid up regulates antioxidant enzyme gene expression and enzymatic activity in diabetic rat kidneys through an O-GlcNAc-dependent mechanism. Eur J Nutr 2013;52:1461-73.

32. Jacob S, Henriksen EJ, Tritschler HJ, Augustin HJ, Dietze GJ. Improvement of insulin-stimulated glucose-disposal in Type 2 diabetes after repeated parenteral administration of thioctic acid. Exp Clin Endocrinol Diabetes 1996;104:284-8.

33. Bitar MS, Wahid S, Pilcher CW, Al-Saleh E, Al-Mulla F. Alpha-lipoic acid mitigates insulin resistance in goto-kakizaki rats. Horm Metab Res 2004;36:542-9.

34. Kamenova P. Improvement of insulin sensitivity in patients with Type 2 diabetes mellitus after oral administration of alpha-lipoic acid. Hormones (Athens) 2006;5:251-8.

35. Packer L, Kraemer K, Rimbach G. Molecular aspects of lipoic acid in the prevention of diabetes complications. Nutrition 2001:17:888-95.

36. Sunde RA. Bowman B, Russell R, editors. Selenium. In: Present Knowledge in Nutrition. $9^{\text {th }}$ ed. Washington, DC: International Life Sciences Institute; 2006. p. 480-97.

37. Whanger P, Vendeland S, Park YC, Xia Y. Metabolism of subtoxic levels of selenium in animals and humans. Ann Clin Lab Sci 1996;26:99-113.

38. Stapleton SR. Selenium: An insulin-mimetic. Cell Mol Life Sci 2000;57:1874-9.

39. Steinbrenner H, Speckmann B, Pinto A, Sies H. High selenium intake and increased diabetes risk: Experimental evidence for interplay between selenium and carbohydrate metabolism. J Clin Biochem Nutr 2011:48:40-5.

40. Wiernsperger N, Rapin J. Trace elements in glucometabolic disorders: An update. Diabetol Metab Syndr 2010;2:70.

41. McNeill JH, Delgatty HL, Battell ML. Insulinlike effects of sodium selenate in streptozocin-induced diabetic rats. Diabetes 1991;40:1675-8.

42. Battell ML, Delgatty HL, McNeill JH. Sodium selenate corrects glucose tolerance and heart function in STZ diabetic rats. Mol Cell Biochem 1998;179:27-34.

43. Douillet C, Tabib A, Bost M, Accominotti M, Borson-Chazot F, Ciavatti M. Selenium in diabetes. Effects of selenium on nephropathy in Type I streptozotocin-induced diabetic rats. J Trace Elem Exp Med 1999;12:379-92.

44. Rahimi R, Nikfar S, Larijani B, Abdollahi M. A review on the role of antioxidants in the management of diabetes and its complications. Biomed Pharmacother 2005;59:365-73

45. Mamun-or-Rashid AN, Hossain S, Hassan N, Dash PK, Sapon A, Sen MK. A review on medicinal plants with antidiabetic activity. J Pharm Phytochem 2014;3:149-59.

46. Prabhakar PK, Doble M. Mechanism of action of natural products used in the treatment of diabetes mellitus. Chin J Integr Med 2011;17:563-74. 
47. Fartyal M. Nerium Oleander Linn. In vitro alpha amylase inhibitory potential of stem and root extracts. Int J Curr Pharm Res 2016;9:37-41.

48. Kaleem M, Asif M, Ahmed QU, Bano B. Antidiabetic and antioxidant activity of Annona squamosa extract in streptozotocin-induced diabetic rats. Singapore Med J 2006;47:670-5

49. Ramya SS, Vijayanand N, Rathinavel S. Antidiabetic activity of Cynodon dactylon (L.) Pers. extracts in alloxan induced rats. Int J
Pharm Pharm Sci 2014;6:348-52.

50. Senthilkumar P, Sudha S, Prakash S. Antidiabetic activity of aqueous extract of Padina boergesenii in streptozotocin-induced diabetic rats. Int J Pharm Pharm Sci 2014;6:418-422.

51. Rajaram K. Antioxidant and antidiabetic activity of Tectona grandis Linn. in alloxaninduced albino rats. Asian J Pharm Clin Res 2013;6 Suppl 3:174-7. 